\title{
Model Pembelajaran Problem Solving Skills Dalam Upaya Peningkatan Kepekaan Masalah Sosial Mahasiswa IPS IAIN Tulungagung Mata Kuliah Ilmu Sosial Dasar
}

\author{
Bagus Setiawan \\ IAIN Tulungagung \\ bagssetya@gmail.com
}

\begin{abstract}
ABSTRAK
Manusia merupakan makhluk sosial yang hidup dimuka bumi ini secara bersama-sama dengan berbagai latar belakang etnis, bahasa, budaya, adad-istiadat yang beraneka ragam serta berbagai permasalahan yang menemani kehidupan sosial tersebut disetiap harinya. Sehingga rentan sekali akan timbulnya masalah sosial, masalah sosial sendiri merupakan suatu kondisi dimana jika di dalam kehidupan sosial antara elemen satu dan elemen lainnya tidak melaksanakan fungsi dan peranannya sesuai dengan nilai dan norma sosial yang berlaku, maka keadaan tersebut masalah sosial. Pendidikan IPS merupakan salah satu mata pelajaran yang dibagun dalam rangka untuk meningkatkan dan menanamkan nilai-nilai sosial. Di kehidupan manusia banyak sekali masalah yang dihadapi dan manusia selalu ingin memecahkan permasalahan tersebut yang sedang dihadapinya. Namun kenyataan pada umumnya masih banyak orang-orang yang belum mampu melakukanya dengan baik. Baik itu permasalahan dalam lingkup yang besar maupun kecil seperti ketimpangan ekonomi, penggusuran, konflik antar etnis, agama, budaya, pemanasan global, isu-isu sosial dan sebagainya.
\end{abstract}

Problem solving skills adalah suatu keterampilan atau proses mental dan intelektual dalam menemukan masalah dan memecahkan berdasarkan data-data dan informasi yang akurat, sehingga dapat diambil sebuah kesimpulan yang tepat dan cermat (Hamalik.1994). Di dalam model pembelajaran problem solving skills ini peserta didik dituntut aktif untuk dapat menggali secara mandiri sebuah permasalahan yang ada disekitar meraka dan berusaha memberikan solusi atau jalan keluar yang sesuai dengan pemikiran peserta didik sendiri.

Tujuan dari penelitian ini yaitu untuk meningkatan kepekaan terhadap masalah sosial mahasiswa-mahasiswa IPS IAIN Tulungagung terhadap fenomena-fenomena sosial, permasalahan sosial, yang mungkin saja sedang terjadi disekitar lingkungan tempat mereka berada.

a. Mahasiswa diharapkan memiliki kepakaan terhadap masalah sosial atau fenomena masalah sosial yang sedang terjadi di sekitar kehidupan mereka di masyarakat. 
b. Mahasiswa diharapkan mampu untuk menyelesaikan permasalahan terhadap fenomena atau masalah sosial yang sedang terjadi dengan analisis berdasarkan data yang mereka kumpulkan secara mandiri.

Dari hasil penelitian dengan judul "Model Pembelajaran Problem Solving Skills Dalam Upaya Peningkatan Kepekaan Masalah Sosial Mahasiswa IPS IAIN Tulungagung Mata Kuliah IImu Sosial Dasar". Hasil jawaban dari 100\% responden bahwa $94 \%$ menyatakan tahu mengenai model pembelajaran problem solving sklills dan $82 \%$ menyatakan mahasiswa IPS IAIN Tulungagung Mata Kuliah IImu Sosial Dasar mampu untuk menemukan masalah sosial sehingga bisa dikatakan mahasiswa cukup peka terhadap masalah yang sedang terjadi di sekitar mereka. Sebanyak 91 responden atau sebesar $87.5 \%$ mahasiswa menyelesaikan masalah yang di temukan dengan solusi atau jalan keluar yang diberikan mahasiswa dalam model pembelajaran problem solving skills yaitu dengan tanggapan tertinggi adalah mampu. Sebesar 94\% menyimpulkan mahasiswa IAIN Tulungagung jurusan IPS dengan mata kuliah ilmu sosial dasar adalah sangat terbantu dengan adanya model pembelajaran problem solving skills dalam pembelajaran. Banyak masalah-masalah sosial yang ditemukan oleh mahasiswa IPS IAIN Tulungagung dan menarik untuk ditindak lanjuti. Masalah tersebut berada di lingkungan masyarakat seperti: Miras dikalangan remaja, Rusaknya moral masyarakat akibat tempat karaoke, kegiatan Judi dan Maraknya sabung ayam di masyarakat, Kerusuhan dan pertikaian antar 2 kubu pencak silat, Tingginya tingkat perceraian tkw, Fenomena game online mobile legend di kalangan remaja dan masyarakat, Lunturnya nilai tata krama anak muda terhadap orang yang lebih tua di masyarakat, dsb.

Kata Kunci: Problem Solving Skills, Masalah Sosial

\section{PENDAHULUAN}

Manusia merupakan makhluk sosial yang hidup dimuka bumi ini secara bersama-sama dengan berbagai latar belakang etnis, bahasa, budaya, adadistiadad, yang beraneka ragam serta berbagai permasalahan yang menemani kehidupan sosial tersebut disetiap harinya. Pendidikan IPS adalah salah satu mata pelajaran yang dibagun dalam rangka untuk meningkatkan dan menanamkan nilai-nilai sosial di masyarakat.

Di kehidupan manusia sehari-hari banyak sekali masalah yang dihadapi dan manusia selalu ingin memecahkan permasalahan tersebut yang sedang dihadapinya. Tetapi kenyataan pada umumnya masih banyak orang-orang yang belum mampu melakukanya dengan sukses, baik itu permasalahan dalam 
lingkup yang besar maupun kecil seperti ketimpangan ekonomi, penggusuran, konflik antar etnis, agama, budaya, pemanasan global, isu-isu sosial dan sebagainya.

Di dalam lingkungan kampus IAIN Tulungagung memberikan sedikit gambaran mengenai bentuk kehidupan sosial yang ada di masyarakat dimana didalamnya terdapat berbagai masyarakat dengan latar belakang yang beragam. Selain itu juga di IAIN Tulungagung juga terdapat jurusan Tadris IImu Pengetahuan Sosial (TIPS) yang merupakan jurusan dengan tujuan salah satunya yaitu untuk dapat menanamkan nilai-nilai sosial di dalam masyarakat, dan mahasiswa IPS bisa dijadikan contoh bagaimana mahasiswa mempunyai rasa kepedulian dan kepekaan sosial di masyarakat.

Potensi besar untuk bisa dilihat sejauh mana para mahasiwa IPS yang mewakili dari jurusan IPS dapat membangun serta menanamkan nilai-nilai sosial di masyarakat lewat kepekaan sosial yang dimiiki mahasiswa dengan pembelajaran problem solving skills yang digunakan. Kampus IAIN Tulungagung mempunyai potensi yang cukup besar dengan mahasiswa di jurusan IPS di semua angkatan yang berjumlah 360 mahasiswa ini dapat memberikan gambaran kepada peneliti seberapa besar mahasiswa dapat melihat kondisi di sekitarnya dan seberapa besar tingkat kepekaan mahasiswa jurusan IPS terhadap masalah sosial yang ada di masyarakat atau tempat sekitar mahasiswa tinggal.

Sampai saat ini masyarakat masih melihat atau memandang mahasiswa sebagai sosok atau seorang yang memiliki pemikiran yang lebih luas serta kritis, Maka dari itu peneliti ingin memberikan materi masalah-masalah sosial di dalam matakuliah ilmu sosial dasar dan melihat seperti apa yang ditemukan oleh mahasiswa terhadap masalah sosial yang ada di sekitar lingkunganya. Berbekal dari pembelajaran problem solving skills dan materi masalah sosial dari peneliti mahasiswa diharapkan mampu memiliki sifat lebih peka kepada keadaan sekitar mereka tinggal atau berada

Pembelajaran IPS merupakan bagian untuk memelihara penanaman nilai masyarakat untuk memecahkan permasalahan yang ada di lingkungan masyarakat. Dalam model pembelajaran problem solving skills ini mahasiswa dituntut wajib untuk secara aktif berinteraksi selama proses pembelajaran berlangsung. 


$\begin{array}{rcr}\text { Sapriya } & \text { menyatakan } & \text { bahwa } \\ \text { pembelajaran } & \text { IPS di } & \text { sekolah } \\ \text { penekanannya } & \text { pada } & \text { aspek }\end{array}$

pengembangan berpikir peserta didik sebagai bagian dari masyarakat untuk berperan serta dalam memecahkan berbagai masalah. (Sapriana.2007) Strategi dalam pembelajaran adalah upaya pembaharuan dalam bidang pendidikan untuk mencapai tujuan pendidikan yang diharapkan. Hal ini akan menuntut mahasiswa untuk dapat lebih aktif dalam mencari materi pembelajaran dengan tepat bahkan mereka akan memperkuat dengan data-data yang mereka butuh kan dan cari secara langsung terhadap permasalahan yang sedang mereka angkat.

Menurut Hamalik, Problem solving merupakan suatu proses mental dan intelektual dalam menemukan berbagai masalah-masalah yang ada dan dapat memecahkan permasalahan tersebut berdasarkan data-data, informasi yang akurat, sehingga dapat diambil kesimpulan yang tepat dan cermat. Problem solving yaitu suatu pendekatan dengan cara mengidentifikasi masalah untuk kemudian dianalisis berdasarkan data yang telah dikumpulkan dengan pemilahan masalah sehingga dapat diterapkan untuk menarik kesimpulan dalam penyelesaian masalah tersebut. Hal tersebut kiranya penting untuk diterapkan atau diaplikasikan di pembelajaran terutama pembelajaran IPS guna untuk mengetahui sejauh mana para mahasiswa IPS tersebut memiliki rasa kepekaan sosial terhadap fenomena atau masalah sosial yang ada di lingkungan sekitarnya.

Berdasarkan latar belakang di atas dirumuskan bahwa masalah penelitian yang diangkat oleh peneliti adalah sebagai berikut:

Apakah penggunaan model pembelajaran problem solving mampu meningkatan kepekaan terhadap fenomena-fenomena permasalahan sosial di masyarakat oleh mahasiswa IPS di IAIN Tulungagung.

Secara khusus masalah dapat dirumuskan seperti berikut:

1. Dengan model pembelajaran problem solving skills apakah mahasiswa IPS semester 2 IAIN Tulungagung dapat menemukan masalah sosial yang ada di masyarakat?

2. Apakah mahasiswa IPS semester 2 IAIN Tulungagung mampu
memecahkan masalah yang
ditemukan di masyarakat? Dalam penelitian ini, peneliti memiliki beberapa tujuan yang diharapkan 
dapat dimiliki serta dicapai oleh mahasiswa-mahasiswa IPS IAIN

Tulungagung, diantara tujuan- tujuan yang ingin dicapai sebagai berikut :

Meningkatan kepekaan mahasiswamahasiswa IPS IAIN Tulungagung terhadap fenomena-fenomena sosial, permasalahan sosial, yang mungkin saja sedang terjadi disekitar lingkungan mereka.

a. Mahasiswa diharapkan memiliki kepakaan sosial terhadap fenomena permasalahan sosial yang sedang terjadi di sekitar kehidupan mereka di masyarakat

b. Mahasiswa diharapkan mampu untuk menyelesaikan permasalahan terhadap fenomena sosial yang sedang terjadi dengan analisis berdasarkan data yang mereka kumpulkan

\section{KAJIAN PUSTAKA}

\section{A. Landasan teori}

Kepekaan terhadap suatu masalah sosial yang ada pada dalam diri seseorang merupakan suatu hal yang sulit untuk dinilai atau dilihat, karena hal tersebut berkaitan dengan diri dalam seseorang individu. Menurut kamus besar bahasa Indonesia (KBBI) kepekaan merupakan kesanggupan bereaksi terhadap suatu masalah atau keadaan. Sedangkan masalah sosial yaitu suatu masalah yang bertentangan dengan nilai-nilai atau norma yang ada di masyarakat. Sehinga bisa dikatakan bahwa kepekaan masalah sosial yaitu suatu tindakan atau reaksi terhadap masalah sosial yang ada di dalam masyarakat. Kondisi tersebut bisa dalam bentuk merasakan suatu masalah, menemukan suatu masalah, bahkan membicarakan atau mendiskusikan suatu masalah yang ada di masyarakat itu bisa dikatakan sebagai peka terhadap masalah sosial.

Kepekaan terhadap suatu masalah sosial pada diri seseorang peserta didik/siswa/mahasiswa terutamanya pada jurusan IPS bisa dibangun dengan model pembelajaran tertentu yang sesuai dengan prinsip dan tujuan pembelajaran IPS. Dimana model pembelajaran tersebut bertujuan untuk membangun atau mengkonstruksi pemikiran peserta didik agar lebih maksimal dalam mengeluarkan ide-ide kreatif secara mandiri dan tentunya harus dengan materi pembelajaran yang tepat atau sesuai pula.

Salah satu model pembelajaran yang sangat sesuai dengan pembelajaran IPS saat ini dan menganut paham konstruktivisme serta bisa diterapkan dalam pembelajaran IPS yaitu model 
pembelajaran problem solving skills. Problem solving skills adalah suatu keterampilan proses mental dan intelektual dalam menemukan masalah dan memecahkan berdasarkan data-data dan informasi yang akurat, sehingga dapat diambil sebuah kesimpulan yang tepat dan cermat (Hamalik.1994). Karena dalam model pembelajaran ini siswa dituntut aktif untuk dapat menggali secara mandiri sebuah permasalahan yang ada disekitarnya dan berusaha memberikan solusi atau jalan keluar yang sesuai dengan pemikiran siswa sendiri.

Problem solving skills sendiri merupakan sebuah kemampuan atau keterampilan dalam menyelesaikan suatu permasalahan, dimana keterampilan tersebut dalam menyelesaiakan permasalahan perlu dilatih dengan modelmodel pembelajaran yang berbasis memberi jalan keluar. Dengan begitu banyak dan beragamnya permasalahan yang dihadapi oleh manusia IPS diharapkan mempunyai peran dalam membantu orang-orang untuk dapat mengembangkan kompetensi-kompetensi untuk dapat memecahkan berbagai masalah yang ada tersebut di dalam masyarakat. Dimana apabila dihubungkan dalam dunia pendidikan prinsip dari problem solving skills itu sendiri yaitu membiarkan peserta didik/siswa/ mahasiswa untuk mendifinisikan masalah dan melakukan penelitian untuk dapat memecahkanya.

Dari penelitian terdahulu sebenarnya telah terdapat berbagai penelitian-penelitian yang menggunakan model problem solving. Seperti halnya yang digunakan oleh peneliti Eko Swistoro Warimun pada tahun 2012, yang dalam penelitianya juga menerapkan model problem solving pada pembelajaran fisika yang diampu dengan materi atau tema topik optika pada mahasiswa fisika. Ada beberapa alasan kenapa digunakan model pembelajaran problem solving yang termasuk dalam model pembelajaran inovatif yaitu:

1. Dengan memasuki era informasi dan globalisasi tidaklah mungkin bagi dosen untuk memberikan semua informasi kepada mahasiswa. Diperlukan keterampilan tertentu yang dapat digunakan oleh mahasiswa untuk mengarahkan dirinya belajar secara mandiri sepanjang hayat.

2. Tidak semua aspek pengetahuan dapat diajarkan dengan cara dan strategi sesuai dengan karakteristik mata kuliah yang diajarkan. 
3. Orientasi pada penguasaan target materi telah berhasil dalam kompetensi mengingat jangka pendek, tapi gagal dalam membekali anak memecahkan persoalan dalam kehidupan jangka panjang.4.

4. Hasil penelitian yang dilakukan dalam 25 tahun terakhir tentang otak manusia menunjukkan bahwa drill hanya mengembangkan satu bagian otak manusia yang berfungsi motorik, sementara otak yang berfungsi untuk berpikir dan bernalar belum dioptimalkan.

5. Kurikulum berbasis kompetensi mengharuskan adanya integrasi antara keterampilan dengan penguasaan konsep.

Dari hasil penelitian terdahulu terhadap penerapan model problem solving telah dapat dilihat bahwa model ini benar memberikan manfaat yang besar kepada peningkatan hasil belajar peserta didik Namun pada penelitian yang saya angkat ini cukup berbeda dari hal tujuan dengan peneliti-peneliti terdahulu, dimana tujuan yang biasanya dilakukan oleh peneliti terdahulu adalah yang berkaitan dengan penguasaan materi sedangkan penelitian yang saya angkat bertujuan untuk kemampuan keterampilan/skills dan kepekaan untuk bisa menemukan permasalahan sosial yang ada di lingkungan masyarak bukan hanya sekedar pemahaman materi.

Model problem solving skills ini pada prinsipnya sejalan dengan tujuan pendidikan yaitu untuk mendewasakan siswa/mahasiswa, yang mana salah satu indikator kedewasan siswa/mahasiswa adalah diukur melalui kemandirian berfikir serta solutif sebagai warga masyarakat. Tujuan dari pembelajaran problem solving adalah seperti apa yang dikemukakan oleh Hudojo (2003), yaitu sebagai berikut:

1) Siswa/mahasiswa menjadi lebih terampil dalam menyeleksi informasi yang relevan kemudian menganalisisnya dan akhirnya meneliti kembali hasilnya.

2) Kepuasan intelektual akan timbul dari dalam sebagai hadiah intrinsik bagi siswa./mahasiswa.

3) Potensi intelektual siswa/mahasiswa akan meningkat.

4) Siswa/mahasiswa dapat belajar bagaimana melakukan penemuan dengan melalui tahap-tahap proses melakukan penemuan.

Berkaitan dengan tugas yang diberikan kepada mahasiswa setelah mahasiswa mendapat wawasan atau 
materi mengenai masalah sosial, mahasiswa langsung ditugaskan untuk dapat melihat kondisi sekitar lingkungan mereka berada dan mampu menemukan masalah-masalah sosial yang ada $\mathrm{di}$ masyarakat. Secara umum sulit untuk menjelaskan secara gamblang apa itu yang dimaksud dengan masalah sosial, namun ada beberapa ahli yang memberikan indikator-indikator terkait apa yang disebut dengan masalah sosial seperti yang diungkapkan oleh Parilo (2000) sebagai berikut:

1. Masalah tersebut dapat menimbulkan berbagai kerugian baik keadaan fisik atau mental baik pada individu atau kelompok

2. Masalah tersebut merupakan pelanggaran terhadap satu atau beberapa nilai atau standar yang dimiiki oleh sebagian besar masyarakat atau mereka yang memiliki kekuatan pengaruh di masyarakat.

3. Keadaan yang terus menerus terjadi

4. Memunculkan kebutuhan untuk dipecahkan berdasarkan evaluasi dari berbagai kelompok di masyarakat (Taftazani. 2017)

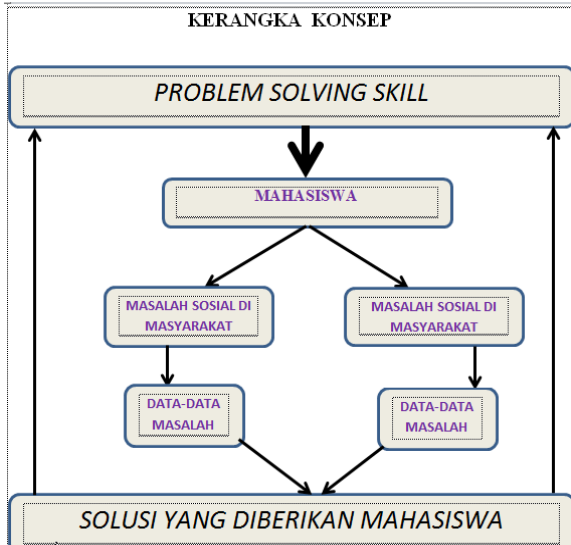

\section{METODE PENELITIAN}

\section{A. Jenis Penelitian}

Penelitian ini akan menggunakan metode survey, yang mana untuk mendapatkan hasil pneliti menarik pendapat dari mahasiswa melakukan percobaan tentang suatu hal serta mengamati prosesnya dari awal hingga akhir hingga menemukan hasilnya yang kemudian di bahas dan di evaluasi oleh dosen pengampu matakuliah. Karena melibatkan mahasiswa dalam penerapan metode problem solving skills setiap pembelajaran dikelas dan di luar kelas maka selanjutnya peneliti mengunakan metode kuantitatif deskriptif untuk mendapatkan hasil penelitian.

Metode kuantitatif deskriptif untuk mempermudah peneliti untuk menjabarkan hasil penelitian dalam bentuk prosentase dengan sedikit penjabaran mengenai hasil yang di dapatkan oleh peneliti. Dengan 
demikian peneliti lebih mudah untuk menganalisis masalah

dan penyelesaiannya.

Adapun langkah awal yang di ambil peneliti atau dosen ialah memberikan pelajaran tentang fenomena atau masalah kehidupan sosial dengan metode pembelajaran problem solving skills yang selanjutnya mahasiswa di berikan tugas oleh dosen pengampu untuk mengamati fenomena atau masalah sosial yang ada di sekitar mereka. Kemudian mahasiswa di berikan pengarahan tentang masalah yang di ambil. Masalah yang di ambil harus memungkinkan untuk di cari data yang relevan. selanjutnya mahasiswa di bagi menjadi beberapa kelompok untuk saling tukar pikiran dan berdiskusi untuk memilih masalah yang mereka temukan.

\section{B. Lokasi Penelitian}

Penelitian ini dilakukan di kampus IAIN Tulungagung, di Desa Plosokandang Kecamatan Jepun Kabupaten Tulungagung untuk mahasiswa jurusan IPS. Dimana mahasiswa IAIN Tulungagung pada umumnya di anggap oleh masyarakat adalah seorang yang mampu untuk berfikir kritis terhadap masalah-masalah yang ada di masyarakat. Oleh karena itu peneliti mengadakan penelitian kepada mahasiswa jurusan IPS yang dianggap mampu memberikan contoh yang baik oleh masyarakat yang memiliki sifat peka terhadap lingkungan sekitar.

\section{Sasaran Penelitian}

Sasaran penelitian dalam penelitian ini adalah mahasiswa IAIN Tulungagung. Mahasiwa disini yang dimaksud yaitu seluruh mahasiwa yang mengikuti mata kuliah ilmu sosial dasar yang di ampu oleh peneliti sebagai dosen pengmpu dengan jumlah mahasiswa jurusan IPS semester 2 di IAIN Tulungagung 104 mahasiswa dengan mata kuliah IImu Sosial Dasar.

\section{Populasi}

Dalam penelitian ini peneliti tidak menggangunakan sampel melainkan menggunakan populasi di jurusan IPS kampus IAIN semester 2 Tulungagung yang mengikuti mata kuliah ilmu sosial dasar yang di ampu oleh peneliti yang berjumlah 104 mahasiswa.

\section{E. Variabel penelitian}

Variabel penelitian adalah obyek penelitian, atau sesuatu yang akan menjadi titik perhatian suatu penelitian (Arikunto,2006). Variabel dalam penelitian ini adalah sebagai berikut :

a) Pengetahuan Mahasiswa

b) Kepekaan Mahasiswa

c) Kemampuan

Menyelesaikan Masalah 


\section{PEMBAHASAN}

Dalam penelitian ini maksudnya bagaimana pendapat kepekaan mahasiswa terhadap lingkungan sekitar dalam meihat masalah sosial dengan menggunakan model pembelajaran problem solving skills:

- Apakah mahasiswa mampu menemukan masalah sosial yang ada di sekitar lingkungan mereka.

- Apakah mahasiswa paham dengan masalah yang mereka temukan.

- Apakah mahasiswa mampu menyelesaikan masalah dan memberikan solusi terhadap masalah yang di temukan.

\section{Tabel 1}

Hasil Kusioner Mahasiswa IAIN Tulungagung Mengenai Pengetahuan Model Pembelajaran Problem Solving Skills

\begin{tabular}{|l|l|l|l|l|l|}
\hline No & Tanggapan & Skor & $\begin{array}{l}\boldsymbol{\Sigma} \\
\text { respo } \\
\text { nden }\end{array}$ & $\%$ & Total \\
\hline 1. & $\begin{array}{l}\text { Sangat } \\
\text { paham }\end{array}$ & 4 & 0 & 0 & 0 \\
\hline 2. & Paham & 3 & 100 & 96 & 288 \\
\hline 3. & Tidak tahu & 2 & 4 & 4 & 8 \\
\hline 4. & $\begin{array}{l}\text { Sangat tidak } \\
\text { tahu }\end{array}$ & 1 & 0 & 0 & 0 \\
\hline Jumlah & & 104 & 100 & 296 \\
\hline
\end{tabular}

Sumber: Perhitungan Primer 2019
Klaifikasi jawaban

- Sangat paham : $339-416$

- Paham : :261-338

- Tidak tahu : :183-260

- Sangat tidak tahu : 104-182

Berdasarkan tabel di atas dapat diketahui bahwa jawaban terbanyak mahasiswa mengenai pengetahuan metode pembelajaran problem solving skills yaitu dengan tanggapan tertinggi adalah paham sebanyak 100 responden atau sebesar $96 \%$. Dengan jumlah skor 288 apabila dibandingkan dengan klasifikasi jawaban di atas maka jawaban 288 responden tersebut termasuk klasifikasi atau kategori paham karena terletak antara 261 - 338, sehingga dapat disimpulkan bahwa mahasiswa IAIN Tulungagung jurusan IPS dengan mata kuliah ilmu sosial dasar adalah paham mengenai metode pembelajaran problem solving skills. 
Tabel 2

Hasil Kusioner Mahasiswa IAIN

Tulungagung Mengenai Kepahaman

Model Pembelajaran Problem Solving

\section{Skills}

\begin{tabular}{|c|c|c|c|c|c|}
\hline No & Tanggapan & Skor & $\begin{array}{c}\boldsymbol{\Sigma} \\
\text { respo } \\
\text { nden }\end{array}$ & $\%$ & Total \\
\hline 1. & $\begin{array}{l}\text { Sangat } \\
\text { paham }\end{array}$ & 4 & 0 & 0 & 0 \\
\hline 2. & Paham & 3 & 98 & 94 & 282 \\
\hline 3. & Tidak tahu & 2 & 6 & 6 & 12 \\
\hline 4. & $\begin{array}{l}\text { Sangat } \\
\text { tidak tahu }\end{array}$ & 1 & 0 & 0 & 0 \\
\hline \multicolumn{3}{|c|}{ Jumlah } & 104 & 100 & 294 \\
\hline
\end{tabular}

\section{Sumber: Perhitungan Primer 2019}

Klaifikasi jawaban

- Sangat paham : : $339-416$

- Paham

$: 261-338$

- Tidak tahu

: $183-260$

- $\quad$ Sangat tidak tahu : $104-182$

Berdasarkan tabel di atas dapat diketahui bahwa jawaban terbanyak mahasiswa mengenai kepahaman problem solving skills yaitu dengan tanggapan tertinggi adalah paham sebanyak 98 responden atau sebesar 94\%. Dengan jumlah skor 282 apabila dibandingkan dengan klasifikasi jawaban di atas maka jawaban 282 responden tersebut termasuk klasifikasi atau kategori paham karena terletak antara 261 - 338, sehingga dapat disimpulkan bahwa mahasiswa IAIN Tulungagung jurusan IPS dengan mata kuliah ilmu social dasar adalah paham mengenai problem solving skills.

\section{Tabel 3}

Hasil Kusioner Mahasiswa IAIN Tulungagung Mampu Menemukan Fenomena Atau Masalah Sosial Yang Tengah Terjadi Di Masyarakat Dalam Model Pembelajaran Problem Solving Skills

\begin{tabular}{|c|c|c|c|c|c|}
\hline No & Tanggapan & Skor & $\begin{array}{c}\boldsymbol{\Sigma} \\
\text { responden }\end{array}$ & $\%$ & Total \\
\hline 1. & $\begin{array}{l}\text { Sangat } \\
\text { mampu }\end{array}$ & 4 & 86 & 82 & 344 \\
\hline 2. & Mampu & 3 & 18 & 18 & 54 \\
\hline 3. & \begin{tabular}{|l|} 
Tidak \\
mampu
\end{tabular} & 2 & 0 & 0 & 0 \\
\hline 4. & $\begin{array}{l}\text { Sangat } \\
\text { tidak } \\
\text { mampu }\end{array}$ & 1 & 0 & 0 & 0 \\
\hline \multicolumn{3}{|c|}{ Jumlah } & 104 & 100 & 398 \\
\hline
\end{tabular}

Sumber: Perhitungan Primer 2019

Klaifikasi jawaban

- Sangat paham : :339-416 
- Paham

$: 261-338$

- Tidak tahu

: $183-260$

- $\quad$ Sangat tidak tahu : $104-182$

Berdasarkan tabel di atas dapat diketahui bahwa jawaban terbanyak mahasiswa yang mampu menemukan fenomena atau masalah yang ada di sekitar dalam metode pembelajaran problem solving yaitu dengan tanggapan tertinggi adalah sangat paham sebanyak 86 responden atau sebesar $82 \%$. Dengan jumlah skor 344 apabila dibandingkan dengan klasifikasi jawaban di atas maka jawaban 344 responden tersebut termasuk klasifikasi atau kategori sangat mampu karena terletak antara 339 - 416, sehingga dapat disimpulkan bahwa mahasiswa IAIN tulungagung jurusan IPS dengan mata kuliah ilmu sosial dasar adalah sangat mampu menemukan fenomena atau masalah yang ada disekitar masyarakat dalam proses pembelajaran problem solving skills.

\section{Tabel 4}

Hasil Kusioner Mahasiswa IAIN

Tulungagung Mengenai Kepahaman

Masalah Sosial Yang Telah Di Temukan

Dalam Model Pembelajaran Problem

Solving Skills

\begin{tabular}{|c|c|c|c|c|c|}
\hline No & Tanggapan & Skor & $\begin{array}{c}\boldsymbol{\Sigma} \\
\text { responden }\end{array}$ & $\%$ & Total \\
\hline 1. & $\begin{array}{l}\text { Sangat } \\
\text { paham }\end{array}$ & 4 & 88 & 85 & 352 \\
\hline 2. & Paham & 3 & 16 & 15 & 45 \\
\hline 3. & Tidak tahu & 2 & 0 & 0 & 0 \\
\hline 4. & $\begin{array}{l}\text { Sangat tidak } \\
\text { tahu }\end{array}$ & 1 & 0 & 0 & 0 \\
\hline \multicolumn{3}{|c|}{ Jumlah } & 104 & 100 & 396 \\
\hline
\end{tabular}

Sumber: Perhitungan Primer 2019

Klaifikasi jawaban

- Sangat paham : $339-416$

- Paham : :261-338

- Tidak tahu : : 183-260

- Sangat tidak tahu : 104-182

Berdasarkan tabel di atas dapat diketahui bahwa jawaban terbanyak mahasiswa mengenai kepahaman fenomena yang di temukan dalam metode pembelajaran problem solving skills yaitu dengan tanggapan tertinggi adalah sangat paham sebanyak 88 responden atau 
sebesar $85 \%$. Dengan jumlah skor 352 apabila dibandingkan dengan klasifikasi jawaban di atas maka jawaban 352 responden tersebut termasuk klasifikasi atau kategori paham karena terletak antara 339 - 416, sehingga dapat disimpulkan bahwa mahasiswa IAIN Tulungagung jurusan IPS dengan mata kuliah ilmu sosial dasar adalah sangat paham mengenai fenomena yang di temukan dalam proses pembelajaran problem solving skills.

\section{Tabel 5}

Hasil Kusioner Mahasiswa IAIN

Tulungagung Mengenai Kemampuan

Menyelesaikan Fenomena / Masalah sosial Yang Telah Di Temukan Dengan

Solusi Dalam Model Pembelajaran Problem Solving Skills

\begin{tabular}{|l|l|l|l|l|l|}
\hline No & Tanggapan & Skor & $\begin{array}{l}\boldsymbol{\Sigma} \\
\text { respo } \\
\text { nden }\end{array}$ & $\%$ & Total \\
\hline 1 & $\begin{array}{l}\text { Sangat } \\
\text { mampu }\end{array}$ & 4 & 91 & 87.5 & 350 \\
\hline 2 & Mampu & 3 & 13 & 12.5 & 37.5 \\
\hline 3 & $\begin{array}{l}\text { Tidak } \\
\text { Mampu }\end{array}$ & 2 & $p$ & 0 & 0 \\
\hline 4 & $\begin{array}{l}\text { Sangat } \\
\text { tidak } \\
\text { Mampu }\end{array}$ & 1 & $p$ & 0 & 0 \\
\hline Jumlah & & 104 & 100 & 387.5 \\
\hline
\end{tabular}

Sumber: Perhitungan Primer 2019
Klaifikasi jawaban

- Sangat paham : $339-416$

- Paham : :261-338

- Tidak tahu $\quad: 183-260$

- Sangat tidak tahu : 104-182

Berdasarkan tabel di atas dapat diketahui bahwa jawaban terbanyak mahasiswa mengenai kemampuan menyelesaikan masalah yang di temukan dengan solusi dalam metode pembelajaran problem solving skills yaitu dengan tanggapan tertinggi adalah paham sebanyak 91 responden atau sebesar $87.5 \%$. Dengan jumlah skor 350 apabila dibandingkan dengan klasifikasi jawaban di atas maka jawaban 350 responden tersebut termasuk klasifikasi atau kategori sangat Mampu karena terletak antara 339 - 416, sehingga dapat disimpulkan bahwa mahasiswa IAIN Tulungagung jurusan IPS dengan mata kuliah ilmu sosial dasar adalah sangat mampu mengenai menyelesaikan masalah yang ditemukan dalam metode pembelajaran problem solving skills. 


\section{Tabel 6}

Hasil Kusioner Mahasiswa IAIN

Tulungungagung Mengenai Kemampuan

Mendiskripsikan Secara Runtut

Fenomena / Masalah Sosial Yang Telah

Di Temukan Dalam Model Pembelajaran

Problem Solving Skills

\begin{tabular}{|l|l|l|l|l|l|}
\hline $\mathbf{N}$ & $\begin{array}{l}\text { Tangga } \\
\text { pan }\end{array}$ & $\begin{array}{l}\text { Sk } \\
\text { or }\end{array}$ & $\begin{array}{l}\boldsymbol{\Sigma} \\
\text { respon } \\
\text { den }\end{array}$ & $\begin{array}{l}\text { Tot } \\
\text { al }\end{array}$ \\
\hline 1 & $\begin{array}{l}\text { Sangat } \\
\text { Mampu }\end{array}$ & 4 & 88 & 8 & 0 \\
\hline 2 & Mampu & 3 & 16 & 1 & 45 \\
\hline 3 & $\begin{array}{l}\text { Tidak } \\
\text { Mampu }\end{array}$ & 2 & 0 & 5 & 0 \\
\hline 4 & $\begin{array}{l}\text { Sangat } \\
\text { tidak } \\
\text { Mampu }\end{array}$ & 1 & 0 & 0 & 0 \\
\hline Jumlah & & 104 & 1 & 38 \\
\hline
\end{tabular}

Sumber: Perhitungan Primer 2019

Klaifikasi jawaban

- Sangat paham : $339-416$

- Paham $\quad: 261-338$

- Tidak tahu $\quad: 183-260$

- Sangat tidak tahu : $104-182$
Berdasarkan tabel di atas dapat diketahui bahwa jawaban terbanyak mahasiswa mengenai mendiskripsikan secara runtut masalah yang ditemukan dalam metode pembelajaran problem solving skills yaitu dengan tanggapan tertinggi adalah paham sebanyak 88 responden atau sebesar 85\%. Dengan jumlah skor 340 apabila dibandingkan dengan klasifikasi jawaban di atas maka jawaban 340 responden tersebut termasuk klasifikasi atau kategori sangat Mampu karena terletak antara 339 - 416, sehingga dapat disimpulkan bahwa mahasiswa IAIN Tulungagung jurusan IPS dengan mata kuliah ilmu sosial dasar adalah sangat Mampu mengenai mendiskripsikan secara runtut masalah yang ditemukan dalam metode pembelajaran problem solving skills. 


\section{Tabel 7}

Hasil Kusioner Mahasiswa IAIN

Tulungungagung Mengenai Pembelajaran

Model Pembelajaran Problem Solving

Skills Untuk Membantu Kemampuan

Proses Pembelajaran.

\begin{tabular}{|c|c|c|c|c|c|}
\hline $\begin{array}{l}\mathrm{N} \\
0\end{array}$ & Tanggapan & Skor & $\begin{array}{c}\boldsymbol{\Sigma} \\
\text { responden }\end{array}$ & $\%$ & Total \\
\hline 1. & $\begin{array}{l}\text { Sangat } \\
\text { membantu }\end{array}$ & 4 & 98 & 94 & 376 \\
\hline 2. & Membantu & 3 & 6 & 6 & 18 \\
\hline 3. & $\begin{array}{l}\text { Tidak } \\
\text { membantu }\end{array}$ & 2 & 0 & 0 & 0 \\
\hline 4. & $\begin{array}{l}\text { Sangat } \\
\text { tidak } \\
\text { membantu }\end{array}$ & 1 & 0 & 0 & 0 \\
\hline \multicolumn{3}{|c|}{ Jumlah } & 104 & 100 & 416 \\
\hline
\end{tabular}

Sumber: Perhitungan Primer 2019

Klaifikasi jawaban

- Sangat paham : $339-416$

- Paham : :261-338

- Tidak tahu $\quad: 183-260$

- Sangat tidak tahu : : 104-182

Berdasarkan tabel di atas dapat diketahui bahwa jawaban terbanyak mahasiswa mengenai problem solving membantu proses pembelajaran yaitu dengan tanggapan tertinggi adalah paham sebanyak 98 responden atau sebesar 94\%. Dengan jumlah skor 376 apabila dibandingkan dengan klasifikasi jawaban di atas maka jawaban 376 responden tersebut termasuk klasifikasi atau kategori sangat membantu karena terletak antara 339 - 416, sehingga dapat disimpulkan bahwa mahasiswa IAIN Tulungagug jurusan IPS dengan mata kuliah ilmu sosial dasar adalah sangat membantu metode pembelajaran problem solving skills dalam pembelajaran.

\section{KESIMPULAN}

Di dalam penelitian dengan judul 'model pembelajaran problem solving skill dalam upaya peningkatan kepekaan masalah sosial mahasiswa IPS IAIN Tulungagung mata kuliah ilmu sosial dasar', yang melibatkan mahasiswa sejumlah 104 mahasiswa, peneliti mendapat banyak informasi yang didapat dari mahasiswa terkait banyaknya temuan masalah-masalah sosial yang ada di masyarakat dan dapat ditemukan oleh para mahasiswa IPS IAIN Tulungagung.

Hasil penelitian mengenai "Model Pembelajaran Problem Solving Skills 
Dalam Upaya Peningkatan Kepekaan

Masalah Sosial Mahasiswa IPS IAIN

Tulungagung Mata Kuliah IImu Sosial

Dasar" Hasil jawaban dari 100\% responden bahwa $94 \%$ menyatakan tahu mengenai metode pembelajaran problem solving sklills dan $82 \%$ menyatakan mahasiswa IAIN Tulungagung pada mata kuliah ilmu sosial dasar mampu menemukan masalah sosial maka bisa dikatakan mahasiswa peka terhadap masalah yang sedang terjadi di sekitar mereka.

Berikut ini adalah masalahmasalah sosial yang ditemukan dan diangkat oleh mahasiswa dalam proses pembelajaran model problem solving skills dengan materi masalah-masalah sosial pada mata kuliah ilmu sosial dasar: Miras dikalangan remaja, Rusaknya moral masyarakat akibat tempat karaoke, Kegiatan judi dan maraknya sabung ayam di masyarakat, Kerusuhan dan pertikaian antar 2 kubu pencak silat, Tingginya tingkat perceraian tkw, Fenomena game online mobile legend di kalangan remaja dan masyarakat, Lunturnya nilai tata krama anak muda terhadap orang yang lebih tua di masyarakat, Maraknya kegiatan atau acra balap motor liar di kalangan remaja.

\section{DAFTAR RUJUKAN}

Arikunto. 2006. Prosedur Penelitian Suatu Pendekatan Praktek. Jakarta : PT. Rineka Cipta

Budi Muhammad Taftazani. 2017. Masalah Sosial dan Wirausaha Sosial. Social work jurnal. Volume:7. No: 1

Depdikbud.1997.Pokok-pokok Pengajaran Biologi dan Kurikulum 1994, Jakarta: Depdikbud.

Eko Swistoro. 2012. Penerapan Model Pembelajaran Problem Solving Fisika Pada Pembelajaran Topik Optika Pada Mahasiswa Pendidikan Fisika. Jurnal Exacta, Vol. X. No. 2

Hamalik Oemar. 1994. Media Pendidikan, Bandung: Cipta Aditya.

Hudojo. 2003. Pengembangan Kurikulum dan Pembelajaran Matematika, Malang: JICA.

Sapriya, 2007. Pembelajaran dan Evaluasi Hasil Belajar IPS, Bandung: UPI PRESS. 